- Insight is the foundation upon which great research reports are built, but structure, style, and substance are needed to communicate that insight.

\section{How to Write a Great Research Report}

\section{"Information is cheap; insight is priceless," says one expert}

BY CHRISTOPHER WRIGHT

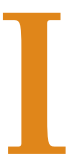

t has come to be known as "the salty snack report." Now legendary among Morningstar analysts as a prime example of what not to do, the report about PepsiCo devoted six to seven pages to an arcane discussion of the salty snack market in Argentina, a topic that was only relevant to a single division of the company (Frito-Lay) and could not possibly move the dial on Pepsi's share price.

Although Pat Dorsey, CFA, research director at Chicago-based Morningstar, doesn't recall which investment firm produced the analysis, he still considers it the worst report he has ever seen. In fact, "Oh no, not another salty snack report" has become code at Morningstar for missing the big picture and getting lost in the details, according to Dorsey, author of The Five Rules for Successful Stock Investing and The Little Book that Builds Wealth.

Susan Mach, a partner at communication strategy firm Mach Creative Services, predicts that the analysts left standing after the global recession will all have one thing in common-strong writing skills.

"No matter how brilliant a researcher you are, you will not get the career you deserve unless you are a strong writer," says the adjunct professor of communication at the New York University Stern School of Business. In addition to her other roles, Mach has twice run a hands-on, three-hour report-writing workshop for the New York Society of Securities Analysts known as the "Top Tips for Writing Great Research Reports."

Mach divides the attributes of a great report into structure, style, and substance, but in her view, no report can be great without one critical ingredient-insight.

Insight. Inexperienced analysts have a tendency to bury readers under a blizzard of details, but more information is not necessarily better. "Information is cheap; insight is priceless," says Dorsey. "The job of the analyst is to separate one from the other."

Insight is the foundation upon which great research reports are built. Mach remembers a group of her business school students who wrote a glowing report on Enron shortly before the firm crashed and burned. "I should really go back and change their grades," she says. "They obviously got snookered."

"You will never find a mispriced security by having the same opinion as the market," says Dorsey. "If your expectations are in line with the market, you have-congratulations! - just found a fairly valued stock."

A five-paragraph company description is worthless. The job of the report writer is to identify which of the company's divisions will create the most value in coming years and which will face headwinds. "You can write a great research report in five pages if you understand the business, distill things down, and say whether the stock price fairly reflects your expectations," says Dorsey.

Structure. The structure of the report dictates how quickly readers can grasp the key points. After you finish your research and sit down to write, begin with your conclusion. Build the investment case the way an attorney prepares for a trial by starting with the closing argument and working back from there. Put a thesis paragraph at the top of the front page that states your conclu-
- Great reports have an easy-to-skim structure, a simple and direct style, and substance readers can't find anywhere else.

- An analyst's fieldwork with noncompany sources is key to determining whether the security is fairly valued.

sion and rationale and gives the reader a map of where the discussion is headed. Also, make the report easy to skim, with sections clearly marked and key points bulleted, in boldface type, or otherwise highlighted for instant accessibility. Don't leave key points buried in the text or make the reader hunt for them later.

Style. Not only is insight the key to reaching the right conclusion, it is the mother of clarity. Clear writing depends on clear thinking. Your conclusions may be simple and readers may effortlessly glide through your prose, but that's only because you put the time and effort into disentangling the disparate strands of thought you encountered along the way and getting to the heart of things. "If it was easy to read, it was hard to write," Mach says.

Also, with regard to style, the quickest way to destroy your credibility is to hand in a report replete with misspelled words, grammatical errors, and poor diction. Keep your audience in mind. The report you write for journalists will be different from the one you write for investors, analysts, or executives to deliver on a conference call. Be simple and direct (the title of a great book on writing by Jacques Barzun). Avoid jargon and big words when common expressions will do. Use the active voice ("the company earned a million dollars," not "a million dollars was earned by the company"). Turn phrases into adjectives ("an aboveconsensus earnings estimate," not "an earnings estimate that is above 
consensus").

In short, be concise. Your report may be competing with e-mail and other reports while your boss is at the gate waiting for a plane. "Write short paragraphs of no more than 810 lines," advises Debra Fiakas, CFA, managing member of Crystal Equity Research in New York City. "People want to read reports fast, fast, fast."

Substance. The key to shareholder value will be different for each company. It might be a deep bench, a distinctive culture, or the ability to grow the top line in a recession. But for Tim Baker, CFA, no report is complete without an earnings forecast, a risk section, and a valuation. Currently director of new business development for New York-based Integrity Research Associates, which helps institutions find research providers, Baker reviewed a lot of reports in his former position as a head of research at UBS.

Earnings forecasts should be presented in a range. "An analyst's single-point estimate is almost by definition going to be wrong," says Baker. Even if the analyst is eventually proven right, he points out, "the client will almost certainly have a different view of the earnings outcome." Include a sensitivity analysis that shows the probable effect on earnings of swings in commodity prices, prices the company can get from customers, or other important variables. For this purpose, according to Baker, Porter's five-forces model $^{*}$ still provides a good framework. (The five forces are threats from substitutes, rivals, and new entrants plus the bargaining power of suppliers and customers.) Lay out scenarios that show, for example, what a 10 percent miss in expected sales volume would do to earnings. Present the results in a table so readers can grasp the relevant factors and range of potential outcomespessimistic, base case, and optimistic — at a glance.

* A framework for analyzing industries and developing business strategies, the five-forces model was developed by Michael Porter of Harvard Business School in 1979.
A risk section will discuss such things as governance problems, related-party transactions that may degrade the quality of earnings, the laddering of debt maturities and how refinancing will affect financial statements, and other company-specific risks. Sector-specific risks, such as commodity prices or country political risks, should also be included.

As for valuation, explain why the stock is cheap or expensive relative to historical multiples and the company's peers. Identify catalysts (i.e., what will propel the share price going forward), whether they involve a new product launch, a pending acquisition, or other event. A lot of

\section{"You will never find a mispriced security by having the same} opinion as the market. If your expectations are in line with the market, you have-congratulations! - just found a

PAT DORSEY, CFA

stocks are cheap, Baker says, but some deserve to be. So, discuss whether a low assigned multiple means the company is truly a bargain or just a value trap.

For David Taube, CFA, founder and president of Kalorama Wealth Strategies in Washington, D.C., a good report will "include as much information as can be obtained independently outside the company being researched." Baker agrees. Instead of relying solely on information that management hands out, do some primary research and fieldwork of your own to support your investment thesis, Baker advises. For example, citing evidence from the channel that a new product launch will be well received will support an above-consensus earnings estimate.
"The good analysts are out there doing their own sleuthing," Baker says.

Another stop on the road to unique money-making insightor what Michael Steinhardt calls "variant perception" in his book No Bull - is to check whether all the components of your analysis point to the same conclusion. If your discounted cash flow (DCF) analysis is at odds with your earnings multiple analysis, watch out. Suppose your DCF valuation puts the stock at 30 times earnings, but the multiple has never gone above 12 in reality. Choosing the naive DCF result as your target share price would not necessarily be wrong, but it would certainly be suspect and would require further justification. Explain why you think the market will respond to growth in the business the way you anticipate.

If Dorsey's subordinates merely state conclusions, he sends their reports back to them. If an analyst believes sales will grow or margins expand, Dorsey will want the report to contain the supporting reasoning and describe the dynamics that will drive the results the analyst expects.

"Get to the point quickly, make your opinion clear, back it up, and tell readers something they don't know," Dorsey says. If you can do that, the greatest research report ever written will be the one you're writing next.

Christopher Wright, an award-winning writer in Arlington, Virginia, publishes his own investment newsletter and country risk reports.

\section{RECOMMENDED RESOURCES}

"Analyzing Investment Research Can Help Investors Weather a Turbulent Market" CFA Institute Press Release (6 February 2008) (www.cfainstitute.org)

"Research Objectivity Standards for Sell-Side Investment Research Firms"

CFA Institute Centre for Financial Market Integrity (www.cfainstitute.org/centre) 